\title{
Effect of Harvesting Age of some Sugar Beet Varieties Grown in a New Reclaimed Soil in Sohag
}

\author{
Ahmed F.I. Gadallah and Sahar, F. Tawfik ${ }^{1}$
}

\begin{abstract}
Two field experiments were carried out at western desert of Sohag Governorate, Egypt (latitude of $26^{\circ} 61^{\prime} \mathrm{N}$, longitude of 31? 52 ' $E$ and altitude of $72 \mathrm{~m}$ ) in 2015/2016 and 2016/2017 seasons to find out the optimal plant age at harvest (180, 195 and 210 days from sowing) of the three multi-germ sugar beet varieties namely Hosam, Sahar and Kawemira under condition of a new reclaimed soil in Sohag. A Randomized complete blocks design using a splitplot arrangement with four replications was used in both seasons, where the main plots were devoted for sugar beet varieties, while plant ages of harvesting were randomly distributed in the sub plots.
\end{abstract}

The results showed that sugar beet varieties differed significantly in all studied traits. Hosam variety was superior in root length, root yield/fed and root fresh weight/plant in both seasons. However Kawemira variety had the thickest root diameter and heaviest top fresh weight/fed in both seasons, as well as TSS\% in the ${ }^{\text {st }}$ one. Sahar variety attained the highest values of sucrose and sugar yield/fed in both seasons, in addition to TSS\% and purity $\%$ in the $2^{\text {nd }}$ one.

delaying harvesting from 180 up to 210 days from sowing increased significantly root length, diameter and root fresh weight/plant, root and sugar yield/fed as well as TSS and sucrose $\%$ in both seasons and purity $\%$ in the $1^{\text {st }}$ one. Beets harvested at age of $\mathbf{1 8 0}$ days attained the highest value of top fresh weight/fed in both seasons.

Interactions between sugar beet varieties and ages of harvesting were significant except purity $\%$, in the $1^{\text {st }}$ season. In the $2^{\text {nd }}$ one, TSS, sucrose $\%$, root and sugar yield/fed were significantly affected by the interaction between the two factors.

Under the conditions of this work, harvest sugar beet Hosam and Sahar varieties after 210 days after sowing can be recommended to obtain the highest root and sugar yields/fed in the new reclaimed soil in Sohag Governorate.

Key Wards: harvesting age, quality, root yield, sugar beet variety.

\section{INTRODUCTION}

Sugar beet (Beta vulgaris var. saccharifera, L.) is the second source of sugar all over the world, while it is considered the most important crop for extraction sugar in Egypt. Since sugar beet crop can be grown in a wide range of soils and climates, expanding of its cultivated area in sandy lands became a possible solution to minimize the increasing demand for sugar. Meantime, all sugar beet genotypes cultivated in Egypt are imported from foreign countries. Therefore, this study was conducted to evaluate some of them under Egyptian conditions especially under newly reclaimed soils in different sowing dates and harvesting ages to make a varietal map to define the best varieties for each area as the sandy soils in west of Sohag governorate. The differences between varieties in gene make-up expression may throw some light on the relative importance of studying varieties performance throughout the growing season. Aly, et al. (2011) reported that sugar beet cultivars differed significantly in studies traits, where Kawemira variety showed the superiority in root fresh weight/plant, root and sugar yields/fed, while, LP12 and Demapoly varieties had the highest value for sucrose, extraction sugar and extractability percentages. Ramadan and Nassar (2004) and Azzazy, et al. (2007) found great variation among sugar beet varieties in yield, quality and its components. Enan, et al. (2009) found that sugar beet varieties differed significantly in all studied traits except TSS\%. Farida variety gave a significant increase for sugar yield, TSS, sucrose and purity\%, while it recorded the lowest values of impurities ( $\mathrm{Na}, \mathrm{K}$ and $\mathrm{N} \%$ ). Abd ElAal, et al. (2010) revealed that sugar beet varieties showed significant variation in yield productivity and root quality. Kawemira and Gloria varieties gave the highest sugar yield followed by Nejma.

Enan, et al. (2011) obtained significant difference among sugar beet varieties in their yield potential. Cleopatra variety recorded the highest sucrose\%, while Florima and Heracule varieties produced the highest root and sugar yields/fed. Aly, et al. (2012) found that sugar beet varieties significantly differed in root length, diameter, root fresh weight/plant, sucrose $\%$, purity $\%$ and root and sugar yields/fed, root mineral content. Kawemira variety surpassed Sultana and Top in most studied traits. Aly (2012) evaluated three sugar beet varieties Kawemira, Carola and Farida. He fond that sugar beet varieties differed significantly in all study characters and that Carola variety was superior in root and top fresh weight/plant, sucrose $\%$, TSS, purity\% root and sugar yields/fed. Al-Labbody, et al. (2012) revealed that Farida and Sultan varieties significantly varied in root length, diameter, root fresh weight, out yielded the other varieties in root and sugar, sucrose $\%$ and impurities\%. Farida variety was superior in sucrose $\%$ and low impurities\%, while Sultan variety

${ }^{1}$ Sugar Crops Res. Inst., Agric. Res. Center, Giza, Egypt

Received December 05,2017, Accepted December 31, 2017 
significantly recorded the best values of root diameter, root fresh weight/plant, purity\%, root and sugar yields/fed. Afez (2016) indicated that sugar beet varieties significantly differed for root length, diameter, TSS $\%$, sucrose $\%$, sugar, top and root yields/fed. Bersea variety surpassed Danube and Tilman varieties in most studied traits.

Harvesting age is one of the main factors directly affects maturity and consequently juice quality and ultimately the expected root and sugar yields of sugar beet. In this respect, Aly (2006) harvested sugar beet at age of 180, 190 and 210 days. He found that delaying harvest dates up to 210 days from sowing increased significantly root length and diameter, sucrose $\%$, root and sugar yields/fed. Nasr and Abd-El-Razek (2008) found that harvesting sugar beet after 210 days from sowing recorded the highest root weight, sucrose and purity percent as well as root and sugar yields/fed compared to that harvested at 170 and 190 days after sowing. Mahmoud, et al. (2008) mentioned that the maximum root and sugar yields/fed were obtained when sugar beet was harvested at 180-210 days after sowing. They added that varying varieties and harvesting dates effected sucrose and juice purity percentage, root and sugar yields/fed. El-Sheikh, et al. (2009) reported that delaying harvest dates from 180 to 210 days attained a gradual and significant effect on sucrose $\%$ and sugar yield as well as root fresh weight/plant and root and sugar yields/fed. They added that the difference between 180 and 195 days was negligible. Aly, et al. (2011) found that delaying harvest date from 175 to 205 days after sowing led to significant increases in root fresh weight/plant, root and sugar yield/fed as well as significant improvement in juice quality (sucrose\%, extraction sugar\% and extractability\%). Aly (2012) and
Hussein, et al. (2012) and found that late harvesting of sugar beet (210 days after sowing) gave the highest root dimension (length and diameter), root yield/fed, the best quality (sucrose and TSS\%) and root and sugar yields compared with harvesting it at 180 days after sowing. Mohamed and Yasin (2013) reported that delaying harvesting date up to 210 days after sowing significantly increased yields of root and sugar/fed, compared with 180 days. Awad, et al. (2015) tested three sugar beet cultivars namely Juvena, Mashad and Valentina under six harvesting age intervals of 4.5, 5.0, 5.5, 6.0, 6.5 and 7.0 months. They cleared that the maximum sucrose content was attained at age of 4.5 and 5.0 months. Beet cultivar Valentina maintained reasonably high sucrose level till age of 5.5 (March $30^{\text {th }}$ ) as the adapted cultivar Juvena. Best harvesting date was early Febuary to early March for all beet varieties tested. There was a severe decline in sugar content at age older than 6 months. This study was conducted in the new lands west of Sohag governorate.

\section{MATERIALS AND METHODS}

A field experiments were carried out at western desert of Sohag Governorate, Egypt (latitude of 26 61' $\mathrm{N}$, longitude of 31 ? $52^{\prime} \mathrm{E}$ and altitude of $72 \mathrm{~m}$ ) in $2015 / 2016$ and 2016/2017 seasons to find out the optimal plant age at harvest $(180,195$ and 210 days from sowing) of the three multi-germ sugar beet varieties namely Hosam, Sahar and Kawemira under conditions of a new reclaimed soil in Sohag. A Randomized complete blocks design using a split-plot arrangement with four replications was used in both seasons, where the main plots were devoted for sugar beet varieties, while plant ages of harvesting were randomly distributed in the sub plots.

Table 1. physical and chemical properties of the experimental sites

\begin{tabular}{lccc}
\hline & Soil property & $\mathbf{2 0 1 5 / 2 0 1 6}$ & $\mathbf{2 0 1 6 / 2 0 1 7}$ \\
\hline \multirow{3}{*}{ Physical analysis } & Sand \% & 87.78 & 86.89 \\
& Silt \% & 5.01 & 4.90 \\
& Clay \% & 7.21 & 8.21 \\
& & Sandy & 0.14 \\
& $\mathrm{Co}_{3}^{-}$ & 0.12 & 0.4 \\
Chemical analysis & $\mathrm{HCo}_{3}^{-}$ & 0.3 & 21 \\
& $\mathrm{Cl}^{-}$ & 20 & 2.7 \\
& $\mathrm{So}^{--}$ & 2.7 & 0.21 \\
& $\mathrm{Ca}^{++}$ & 0.20 & 1.9 \\
& $\mathrm{Mg}^{++}$ & 1.8 & 22 \\
& $\mathrm{Na}^{+}$ & 21 & 0.13 \\
& $\mathrm{~K}^{+}$ & 0.12 & 2.6 \\
\hline
\end{tabular}

Maximum and minimum monthly temperature $\left({ }^{0} \mathrm{C}\right)$, relative humidity $(\%)$ and wind speed $(\mathrm{m} / \mathrm{sec})$ as elucidated in Table $(2)$. 
Table 2. Average values of meteorological data recorded at Shandaweel Agricultural Research Station in 2015/2016 and 2016/2017 growing seasons

\begin{tabular}{|c|c|c|c|c|c|}
\hline \multirow[b]{2}{*}{ Month } & \multicolumn{2}{|c|}{ Temp. degrees, ${ }^{\circ} \mathrm{C}$} & \multicolumn{2}{|c|}{ Relative humidity \% } & \multirow[b]{2}{*}{$\begin{array}{c}\text { Wind speed } \\
(\mathrm{m} / \mathrm{sec})\end{array}$} \\
\hline & T. $\max$. & T. min. & $\begin{array}{l}\text { Max. } \\
\text { RH\% }\end{array}$ & Min. RH\% & \\
\hline October 2015 & 36.7 & 19.0 & 84.5 & 24.9 & 16.3 \\
\hline November 2015 & 30.6 & 11.2 & 90.2 & 18.7 & 16.1 \\
\hline December 2015 & 23.9 & 5.2 & 93.2 & 21.2 & 15.6 \\
\hline January 2016 & 20.5 & 2.4 & 83.3 & 18.4 & 7.9 \\
\hline February 2016 & 27.8 & 8.1 & 68.2 & 15.1 & 12 \\
\hline March 2016 & 31.3 & 15.2 & 55.6 & 18.9 & 11.5 \\
\hline April 2016 & 37.2 & 17.5 & 48.0 & 13.8 & 10.9 \\
\hline May 2016 & 38.1 & 20.2 & 43.0 & 16.6 & 10.7 \\
\hline October 2016 & 34.3 & 14.8 & 66.9 & 15.6 & 16.1 \\
\hline November 2016 & 29.2 & 10.0 & 70.0 & 15.7 & 16.4 \\
\hline December 2016 & 23.6 & 5.2 & 72.0 & 16.0 & 15.8 \\
\hline January 2017 & 22.5 & 4.8 & 65.4 & 15.6 & 8.0 \\
\hline February 2017 & 24.5 & 6.3 & 57.0 & 14.3 & 13 \\
\hline March 2017 & 29.0 & 11.6 & 50.8 & 15.4 & 12.3 \\
\hline April 2017 & 35.0 & 17.0 & 42.6 & 14.8 & 11.1 \\
\hline May 2017 & 38.3 & 20.4 & 43.5 & 16.8 & 10.8 \\
\hline
\end{tabular}

The experimental unit area was $21 \mathrm{~m}^{2}(1 / 200$ feddan), including 5 rows of $0.6 \mathrm{~m}$ apart and $7 \mathrm{~m}$ in length. Seeds were sown on the $20^{\text {th }}$ and $25^{\text {th }}$ of October in the $1^{\text {st }}$ and $2^{\text {nd }}$ seasons, respectively. Sugar beet crop was planted after fallow in both seasons. The soil of the experimental site was analyzed as shown in Table 1.

Maximum and minimum monthly temperature $\left({ }^{0} \mathrm{C}\right)$, relative humidity (\%) and wind speed $(\mathrm{m} / \mathrm{sec})$ as elucidated in Table (2).

Overall application of Nitrogen, phosphorus and potassium were given to sugar beet plants at $100 \mathrm{~kg} \mathrm{~N}$ (as Urea in 3 doses, after thinning and 3 weeks later), 15 $\mathrm{kg} \mathrm{P}_{2} \mathrm{O}_{5}$ (as superphosphate, $15 \% \mathrm{P}_{2} \mathrm{O}_{5}$ ) and $24 \mathrm{~kg} \mathrm{~K} 2 \mathrm{O}$ (as potassium sulfate, $48 \% \quad \mathrm{~K}_{2} \mathrm{O}$ ) per feddan, respectively.

\section{The recorded data:}

At harvest, the three guarded rows of each plot were harvested and a sample of 10 plants was randomly taken from each plot to determine the following traits:

1. Root length $(\mathrm{cm}) .2$. Root diameter $(\mathrm{cm}) .3$. Root fresh weight $(\mathrm{g})$.

4. Total soluble solids percentage (TSS\%) was determined using "Hand Refractometer".

5. Sucrose \% was estimated polarimeterically in the fresh samples of sugar beet roots, in a lead acetate extraction of fresh macerated root, according to the method of Le Docte (1927).

6. Juice purity\% was calculated using the following equation:

$$
\text { Purity } \%=(\text { sucrose } \% \times 100) / \mathrm{TSS} \% \text {. }
$$

Top, root and sugar yields: Sugar beet plants of the three guarded rows were up-rooted, cleaned, topped and the following parameters were assessed:

1. Top yield/fed (ton).2. Root yield/fed (ton).

3. Sugar yield/fed (ton) was calculated using the following equation:

\section{Sugar yield/fed (ton) $=$ root yield $\mathrm{x}$ sucrose $\%$.}

Data were statistically analyzed according to the method of Gomez and Gomez (1984). The treatment means were compared using the least significant difference (LSD) values at 5\% level of significance.

\section{RERSULTS AND DISCUSSION}

\section{Root length, diameter and fresh weight/plant:}

Data presented in Table 3 show that Hosam variety showed the significant superiority over the other varieties in root length, diameter and root fresh weight/plant. However, Kawemira variety surpassed the other varieties in root diameter at harvesting in both seasons. Differences among the tested sugar beet varieties may be due to their genetical structure. These findings are in line with those reported by Al-Labbody, et al. (2012) and Afez (2016).

Delaying harvest age from 180 to 195 and 210 days gradually and significantly increased root length, diameter and fresh weight/plant. Harvesting sugar beet crop at 210 days resulted in increases of (9.95 and 10.88 $\%),(19.27$ and $21.72 \%)$ and (18.44 and 39.88\%) for root length, diameter and root fresh weight/plant, compared with that harvested after 180 days from sowing, in the $1^{\text {st }}$ and $2^{\text {nd }}$ season, respectively. The 
advantage of increasing the duration from planting to harvesting on these growth traits could be attributed to more dry matter accumulation with the advance of plant age. These results are in accordance with those reported by Aly (2006) and El-Sheikh, et al. (2009).

The interaction between sugar beet variety and harvest age had a significant influence on root length, diameter and root fresh weight/plant in the $1^{\text {st }}$ seasons only.

It was noticed that the difference in root length and diameter between Sahar and Kawemira varieties was insignificant, when they were harvested at age of 210 days after sowing. However, Sahar variety surpassed Kawemira in root length significantly at age of 180 and 195 days, while Kawemira markedly surpassed Sahar in root diameter at the same two earlier ages.

\section{Total soluble solids (TSS), sucrose and purity percentages:}

Data in Table 4 indicate that the evaluated sugar beet varieties differed significantly in TSS and sucrose

Table 3. Effect of harvesting ages of sugar beet varieties and their interaction on root length (cm), root diameter $(\mathrm{cm})$ and root weight $(\mathrm{kg})$ in $2015 / 2016$ and $2016 / 2017$ seasons

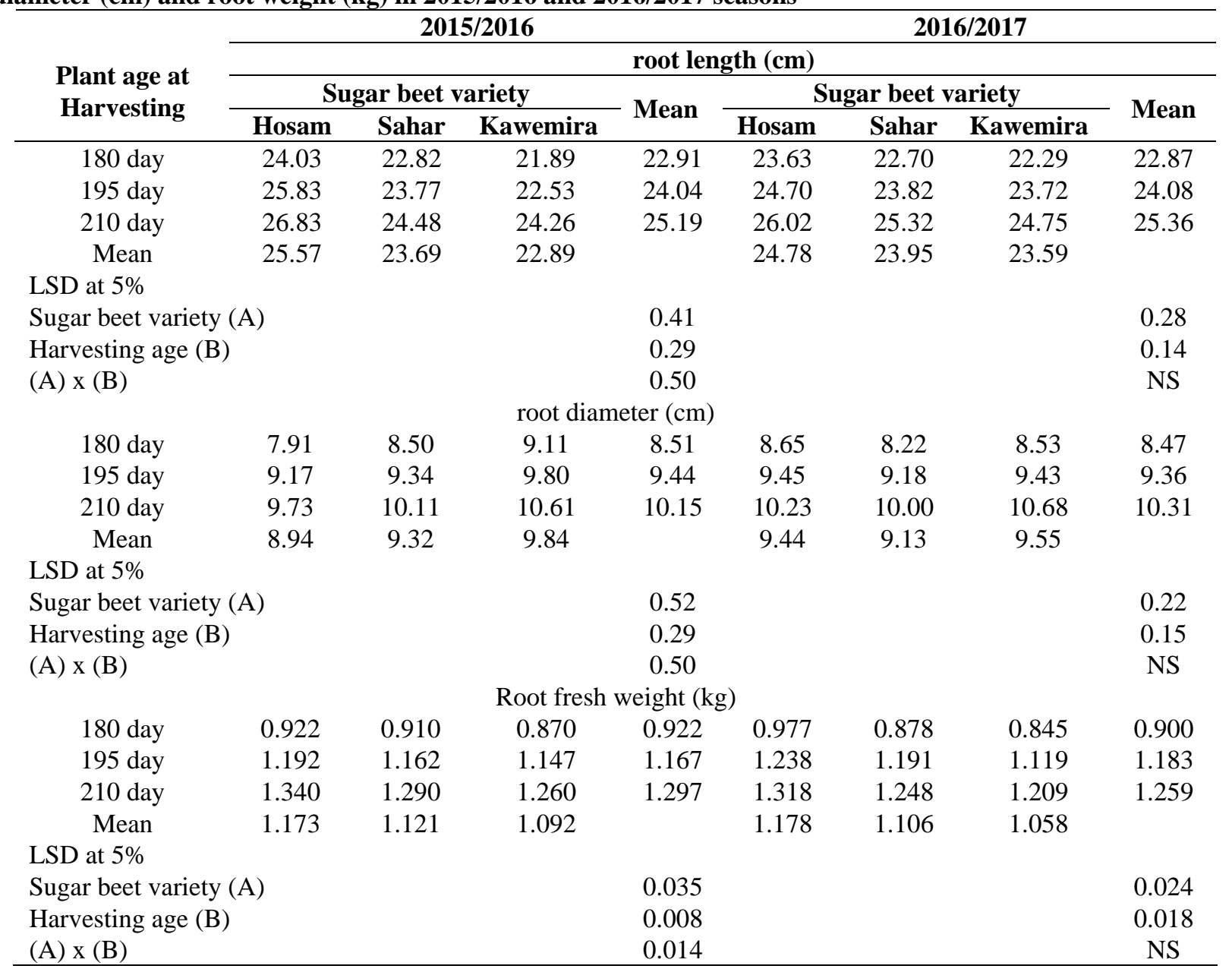

percentage in both seasons, while purity \% was variety attained the highest value of sucrose in the two seasons as well as TSS\% in the $1^{\text {st }}$ season and purity\%, in the $2^{\text {nd }}$ one. However, Kawemira variety superposed the other varieties in TSS $\%$ in the $2^{\text {nd }}$ season. These results are probably correlated to gene make-up of these beet varieties. These results are in accordance with those found by Azzazy, et al. (2007); Enan, et al. (2009); Abd El-Aal, et al. (2010); Aly, et al. (2012); ElLabbody, et al. (2012) and Afez (2016).

Delaying harvesting from 180 up to 195 and to 210 days after sowing, positively and significantly increased TSS, sucrose and purity percentage in both seasons. Harvesting sugar beet at 210 days gave the highest values of TSS, sucrose and purity percentage. These results coincide with those reported by El-Sheikh, et al. (2009); Enan, et al. (2009); Abd El-Aal, et al. (2010); Aly, et al. (2012); Hussein, et al. (2012); Mohamed and Yasin (2013) and Awad, et al. (2015). significantly influenced in the $2^{\text {nd }}$ one. Sugar beet Sahar 
Table 4. Effect of harvesting ages of sugar beet varieties and their interaction on total soluble solids, sucrose and purity percentages in $2015 / 2016$ and $2016 / 2017$ seasons

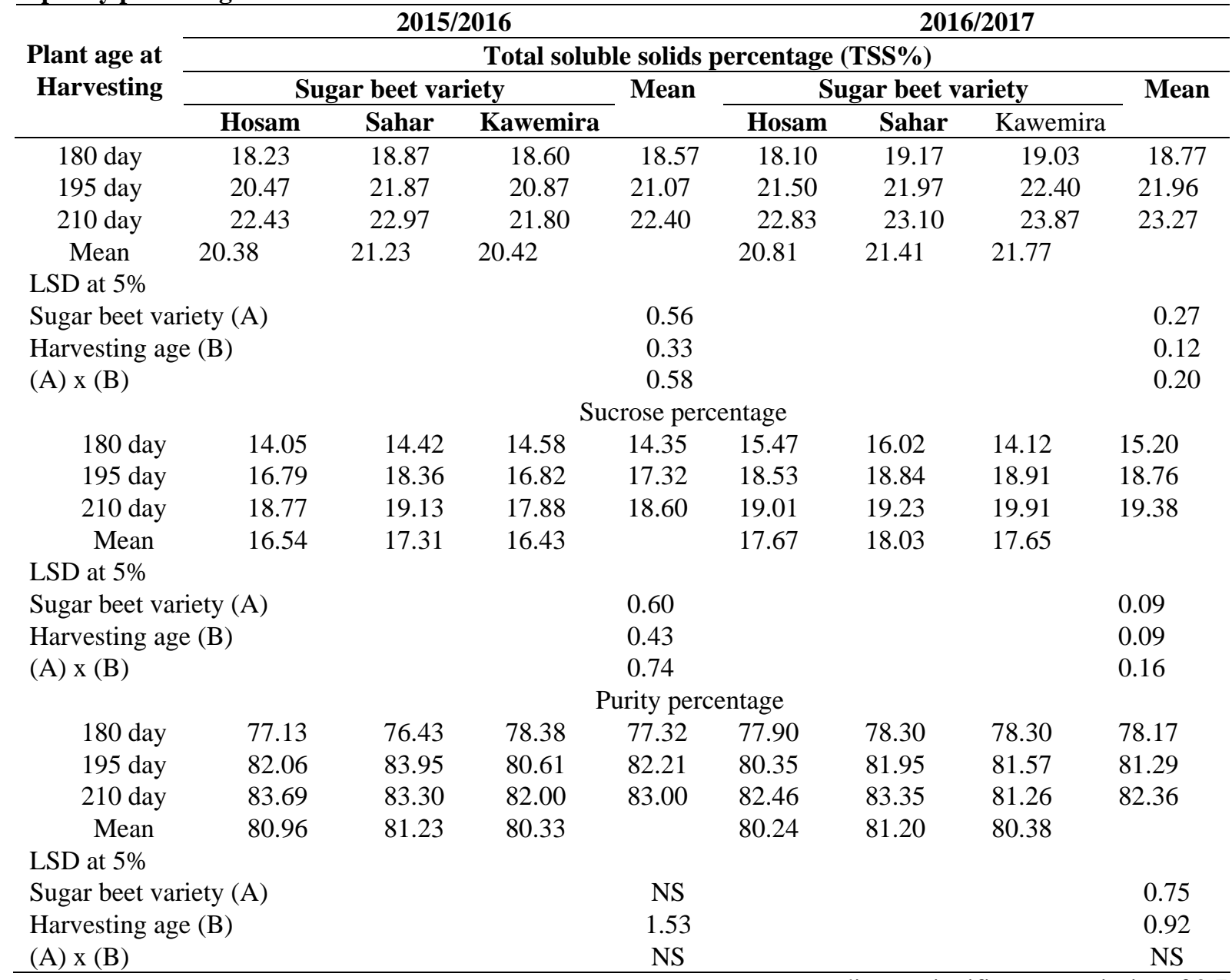

The interaction between sugar beet varieties $\mathrm{x}$ harvest age had a significant effect on TSS and sucrose $\%$ in both seasons. There was no significant variance in TSS and sucrose percentages between Sahar and Kawemira varieties by harvesting them earlier at age of 180 days, while harvesting later ate age of 195 and/or 210 days resulted in the significant superiority of Sahar over Kawemira in the two traits, in the $1^{\text {st }}$ season. Similar tendency was observed with respect to $\mathrm{TSS} \%$, in the $2^{\text {nd }}$ season. Insignificant difference in sucrose $\%$ was recorded between Sahar over Kawemira, when they were harvested at 195 days, with significant variance between them earlier or later harvesting ages, in the $2^{\text {nd }}$ season.

\section{Top, root and sugar yields:}

Results in Table 5 demonstrate that the evaluated varieties of sugar beet significantly differed in top, root and sugar yields/fed. Kawemira variety surpassed significantly Hosam variety by 0.468 ton and Sahar insignificantly by 0.112 ton in top yield/fed, in the $1^{\text {st }}$ season, corresponding to significant superiority of 0.702 and 0.207 ton/fed over Hosam and Sahar, respectively, in the $2^{\text {nd }}$ season.

Hosam variety out-yielded Kawemira variety by 0.289 ton in root yield/fed, without significant difference with Sahar in root yield, in the $1^{\text {st }}$ season. In the $2^{\text {nd }}$ one, Hosam variety attained a substantial increase of 0.194 and 0.342 ton of roots/fed over that gained by Sahar and Kawemira, successively.

Sahar surpassed Kawemira significantly in sugar yield by 0.256 ton/fed, without marked variance with Hosam, in the $1^{\text {st }}$ season. In the $2^{\text {nd }}$ one, insignificant difference was detected in sugar yield/fed between the evaluated sugar beet varieties.

These observations assured that the final output of the tested varieties was affected by their gene make-up in addition to the surrounded environment. The obtained results are in coincidence with those obtained by Azzazy, et al. (2007); Enan, et al. (2009); 
Table 5.Effect of harvesting ages of sugar beet varieties and their interaction on top, root and sugar yields/fed (ton) in 2015/2016 and 2016/2017 seasons

\begin{tabular}{|c|c|c|c|c|c|c|c|c|}
\hline \multirow{4}{*}{$\begin{array}{l}\text { Plant age at } \\
\text { Harvesting }\end{array}$} & \multicolumn{4}{|c|}{$2015 / 2016$} & \multicolumn{4}{|c|}{$2016 / 2017$} \\
\hline & \multicolumn{8}{|c|}{ Top yield/fed (ton) } \\
\hline & \multicolumn{3}{|c|}{ Sugar beet varieties } & \multirow{2}{*}{ Mean } & \multicolumn{3}{|c|}{ Sugar beet varieties } & \multirow{2}{*}{ Mean } \\
\hline & Hosam & Sahar & Kawemira & & Hosam & Sahar & Kawemira & \\
\hline 180 day & 9.747 & 10.103 & 10.097 & 9.982 & 9.750 & 10.087 & 10.300 & 10.046 \\
\hline 195 day & 8.850 & 9.193 & 9.353 & 9.132 & 8.680 & 9.257 & 9.437 & 9.124 \\
\hline 210 day & 7.750 & 8.117 & 8.300 & 8.056 & 7.557 & 8.127 & 8.357 & 8.013 \\
\hline Mean & 8.782 & 9.138 & 9.250 & & 8.662 & 9.157 & 9.364 & \\
\hline \multicolumn{9}{|l|}{ LSD at $5 \%$} \\
\hline Sugar beet var & $y(A)$ & & & 0.174 & & & & 0.095 \\
\hline Harvesting age & & & & 0.134 & & & & 0.124 \\
\hline \multirow[t]{2}{*}{$(\mathrm{A}) \times(\mathrm{B})$} & & & & 0.232 & & & & NS \\
\hline & \multicolumn{8}{|c|}{ root yield/fed (ton) } \\
\hline 180 day & 24.762 & 24.582 & 24.340 & 24.561 & 24.435 & 24.383 & 24.243 & 24.354 \\
\hline 195 day & 25.378 & 25.352 & 25.194 & 25.308 & 25.561 & 25.323 & 25.116 & 25.333 \\
\hline 210 day & 26.366 & 26.183 & 26.106 & 26.218 & 26.457 & 26.165 & 26.067 & 26.230 \\
\hline Mean & 25.502 & 25.372 & 25.213 & & 25.484 & 25.290 & 25.142 & \\
\hline \multicolumn{9}{|l|}{ LSD at $5 \%$} \\
\hline Sugar beet var & $y(A)$ & & & 0.189 & & & & 0.108 \\
\hline Harvesting age & & & & 0.063 & & & & 0.069 \\
\hline \multirow[t]{2}{*}{ (A) $x(B)$} & & & & 0.110 & & & & 0.119 \\
\hline & \multicolumn{8}{|c|}{ sugar yield/fed (ton) } \\
\hline 180 day & 3.531 & 3.589 & 3.622 & 3.581 & 3.402 & 3.472 & 3.388 & 3.420 \\
\hline 195 day & 4.408 & 4.740 & 4.344 & 4.497 & 4.514 & 4.525 & 4.453 & 4.497 \\
\hline 210 day & 5.100 & 5.171 & 4.766 & 5.012 & 4.835 & 4.905 & 4.888 & 4.876 \\
\hline Mean & 4.346 & 4.500 & 4.244 & & 4.250 & 4.301 & 4.243 & \\
\hline \multicolumn{9}{|l|}{ LSD at $5 \%$} \\
\hline \multirow{3}{*}{\multicolumn{3}{|c|}{$\begin{array}{l}\text { Sugar beet variety (A) } \\
\text { Harvesting age (B) } \\
\text { (A) } \mathrm{x}(\mathrm{B})\end{array}$}} & & 0.195 & & & & NS \\
\hline & & & & 0.100 & & & & 0.064 \\
\hline & & & & 0.174 & & & & 0.111 \\
\hline
\end{tabular}

Abd El-Aal, et al. (2010); Aly, et al. (2012); ElLabbody, et al. (2012) and Afez (2016).

Delaying harvesting age of sugar beet to 195 and 210 days after sowing caused a significant and gradual increase in root yield amounted to (3.05 and 6.75\%) and (4.02 and $7.72 \%$ ), as well as a significant increase in sugar yield of (25.57 and 39.96\%) and (31.49 and $42.57 \%)$. However, top yield/fed decreased by (23.82 and $13.27 \%$ ) and (25.46 and $13.85 \%)$, compared to beets harvested at 180 days, in the $1^{\text {st }}$ and $2^{\text {nd }}$ season, respectively. These increase in root yield/fed accompanied the delay in plant age of harvesting may be due increasing root length, diameter and fresh weight (Table 3), while the increase in sugar yield/fed may be referred to the increase in sucrose and purity percentages (Table 4) as well as the increase in root yield (Table 5).

The interaction of sugar beet variety $\mathrm{x}$ harvest age affected top yield significantly in the $1^{\text {st }}$ season only. It was found that Kawemira variety produced 0.55 ton of tops/fed higher than that given by Hosam, when they were harvested at age of 210 days, while it surpassed Hosam by only 0.35 ton of leaves/fed at the earlier age of 180 days.

Root yield was significantly affected by the interaction between beet variety and harvesting age in both seasons. In the $1^{\text {st }}$ season, insignificant variance in root yield between Sahar and Kawemira was detected, in case of harvesting them lately at 210 days, but Sahar markedly out-yielded Kawemira in this trait at the other earlier harvesting ages. In the $2^{\text {nd }}$ season, Hosam recorded substantial increase in root yield over that produced by Sahar at the earliest harvesting age of 180 days, without any appreciable variance in root yield between the two varieties at 195 and 210 ages.

The interaction between beet variety and harvesting age had a significant influence on sugar yield in the $1^{\text {st }}$ season. It was noticed that the difference between Hosam and Sahar varieties in sugar yield was 
insignificant at the earlier and/or later harvesting age, but Sahar significantly surpassed Hosam in sugar yield at the middle age of harvesting.

\section{CONCLUSION}

Under conditions of the present results revealed that growing each of Hosam and/or Sahar sugar beet varieties and harvesting them at age of 210 days from sowing can be recommended to obtain the highest root and sugar yields/fed in the newly reclaimed soils in Sohag Governorate.

\section{REFERENCES}

Abd El-Aal, A.M., A.I. Nafie and Ranya M. Abdel Aziz. 2010. Response of some sugar beet genotypes to nitrogen fertilization under newly reclaimed land conditions. Egypt. J. Appl. Sci. 25 (6-B): 194-208.

Afez, A.A. 2016. Effect of growth inhibitors and planting dates on some varieties of sugar beet (beta vulgaris. L.). Ph.D. Thesis, Fac. Al-Azhar Univ.

Al-Labbody, A.H.S., A.I. Nafi, and E.F.A. Aly. 2012. Response of some sugar beet varieties to nitrogen sources under the newly reclaimed soil. Egypt. J. Appl. Sci., 27(4): 153-160.

Al-Sayed, M.H., U.A. Abd El Razek, H.M. Sarhan and Hayam S. Fateh. 2012Effect of harvesting dates on yield and quality of some sugar beet varieties. Aust. J. Basic Appl. Sci. 6(9): 525-529.

Aly, E.F. 2006. Effect of environmental conditions on productivity and quality of some sugar beet varieties. Ph.D. Thesis. Fac. Agric., Benha Univ., Egypt.

Aly, E.F.A., A.H.A.A. Al-Labbody and M.S.M. Aly. 2011. Effect of harvesting dates on quality and yield characteristics of some sugar beet varieties. Fayom J. Agric. Res. Dev. 25(1): 230-237.

Aly, M.S.M. 2012. Performance study of some sugar beet varieties under sowing and harvesting dates. J. Plant Prod., Mansoura Univ. 3(9): 2439-2449.

Aly, M.S.M., S.R.E. El Sheikh and M.M. Abd El-Rahman. 2012. Response of some sugar beet varieties to foliar spray with compost tea under newly reclaimed soils. Fayoum J. Agric. Res. Dev. 26(1): 99-105.

Awad, E.M., O.A. Ahmed and Ph.W. Marchelo. 2015. Evaluation of sowing date and harvest age of some sugar beet (beta vulgaris Subsp. vulgaris) cultivars under
Guneid Condition, (Sudan). ISSN-2360-7971. 3(9): pp 421-424.

Azzazy, N.B., N.M.S. Shalaby and A.M. Abd El Razek. 2007. Effect of planting density and days to harvest on yield and quality of some sugar beet varieties under Fayoum condition. Egypt J. Appl. Sci. 22 (12-A): 101-14.

El Sheikh, S.R.E., K.A.M. Khaled and S.A.A.M. Enan. 2009. Evaluation of some sugar beet varieties under three harvesting dates. J. Agric. Sci. Mansoura Univ. 34 (3): 1559-1567.

Enan, S.A.A.M., A.M. Abd El-Aal and N.M.E. Shalaby. 2011. Yield and quality as affected by sowing date and harvest age. Fayom J. Agric. Res. Dev. 25 (2):51-65.

Enan, S.A.A.M., S.R.E. El Sheikh and K.A.M. Khaled. 2009. Evaluation of some sugar beet varieties under different levels of $\mathrm{N}$ and Mo fertilization. J. Biol. Chem. Environ. Sci. 4(1): 345-362.

Gomez, K.A. and A.A. Gomez. 1984. Statistical Procedures for Agricultural Research. John Willey and Sons. Inc. New York.

Hussein M.A., U.A. Abd El Razek, H.M. Sarhan and S. F. Hayam. 2012. Effect of harvesting dates on yield and quality of some sugar beet varieties. Aust. J. Basic Appl. Sci. 6(9): 525-529.

Le Docte process. Int. Sugar J., 29: pp 488-492. [C.F. Draycott, A.P. 1972. Sugar Beet Nutrition. Appl. Sci. Pub. Ltd, London].

Le Docte, A. 1927. Commercial determination of sugar in beet root using the Sacks.

Mahmoud, S.A.,B. Hasanin, I.H. El-Geddawy and D.T.A. Mosa. 2008. Effect of sowing and harvesting dates on yield and quality of some sugar beet varieties. Proc. Int. Conf. (IS-2008), Al-Arish, Egypt. Sep. 11-14, pp. 22-29.

Mohamed, Hanan, Y. and M.A.T. Yasin. 2013. Response of some sugar beet varieties to harvesting dates and foliar application of Boron and Zinc in sandy soils. Egypt. J. Agron. 35 (2): 227-252.

Nasr, M.I. and A.M. Abd El-Razek. 2008. Sugar beet performance under newly reclaimed soils conditions of Sinai, Egypt. Sugar Tech. 3: 210-218.

Ramadan B.S.H. and A.M. Nassar. 2004. Effect of nitrogen fertilization on yield and quality of some sugar beet varieties. Egypt. J. Agric. Rec. 82(3):1253-1268 


\section{الملخص العربي}

\section{تأثير عمر الحصاد لبعض أصناف بنجر السكر المنزرعة فى أرض حديثة الإستصلاح فى سوهاج} أحمد فتحي إبر اهيم جادالله و سحر فايز توفيق

الموسم الأول بزر اعة الصنف كاومير ا - في حين سجل

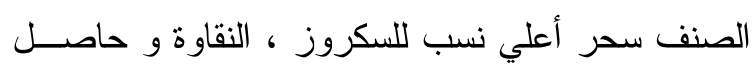

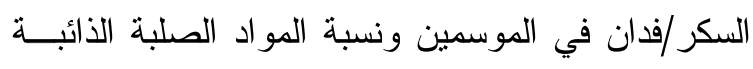
الكلية في الموسم الثاني ، مقارنة بالصنفين الآخرين.

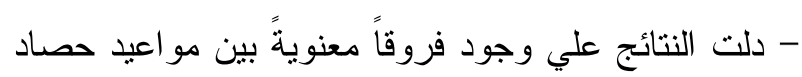

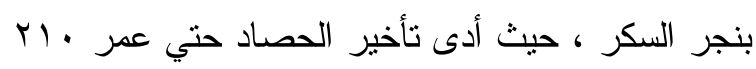

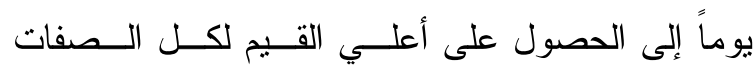

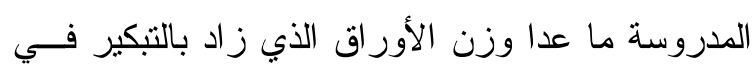

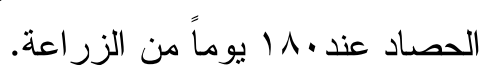

تحت ظروف هذه الدراسة ، يمكن التوصية بزر اعة أيٍ

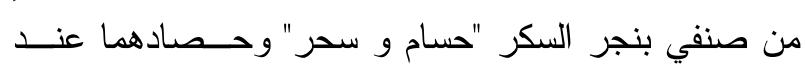

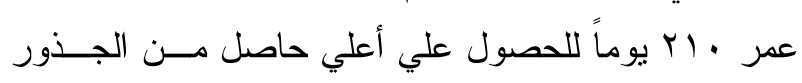
و السكر للفدان في الأر اضى حديثة الإستصلاح فى محافظة

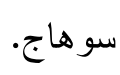

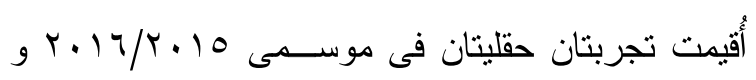

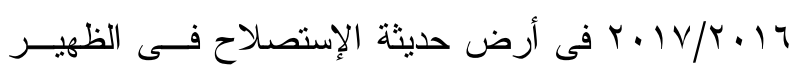

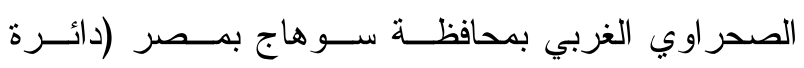

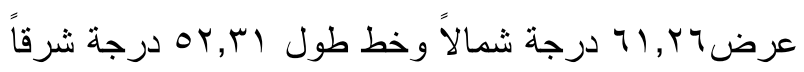
و إرتفاع VY متر اً عن سطح البحر) بهدف در اســـة تــأثير

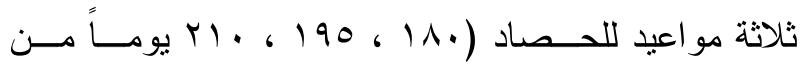

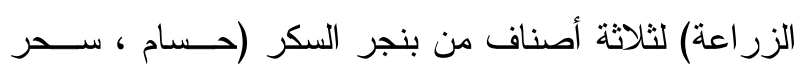
وكاومير ا). باستخدام تصميم القطع المنشقة مره و احدة فـي لني

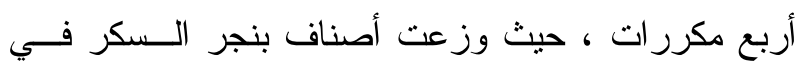
القطع الرئيسية وعدد الأيام حتى الحصاد في القطع الـشقية وكانت أهم النتائج المتحصل وعل عليها هي: - تفوق الصنف حسام علي الصنفين سحر وكــاومير ا فـي

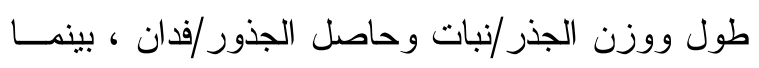

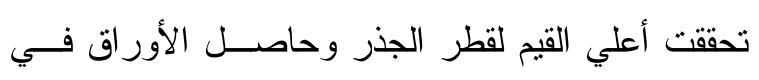

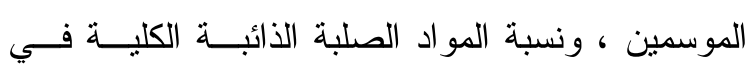

